\title{
NOTES ON THE NESTS AND EGGS OF CERTAIN
}

\section{AUSTRALIAN BIRDS.}

\author{
By A. J. North.
}

\section{Artamus melanops, Gould.}

This species is found plentifully dispersed throughout the interior of South Australia, and the Darling and Albert districts of New South Wales. The nest is a round, open structure, composed of fibrous roots, lined inside with grasses, and placed in a low bush. Eggs four in number for a sitting, varying considerably in the character of their markings.

A set taken by Mr. K. H. Bennett at Mossgiel, on the 17 th of October, 1886, are of a fleshy-white, thickly freckled and spotted with irregularly shaped markings of reddish-brown, and others of a bluish-grey tint appearing as if beneath the surface of the shell. Length (A), $0.87 \times 0.69$ inch; (B), $0.9 \times 0.67$ inch; (C), $0.85 \times$ 0.67 inch; (D), $0.89 \times 0.68$ inch.

Another set of a reddish-white ground colour are heavily blotched all over, but particularly towards the larger end, with bright red and a few indistinct obsolete spots of deep bluish-grey. Length (A), $0.82 \times 0.68$ inch; (B), $0.87 \times 0.67$ inch; (C), 0.89 $\times 0.67$ inch; (D), $0.87 \times 0.68$ inch. Taken by Mr. James Ramsay at Tyndarie, November 2nd, 1879.

The months of September, October, and November constitute the breeding season of this species.

\section{Strepera intermedia, Sharpe.}

A single egg of this species in the Dobroyde collection, taken at Mount Gawler, South Australia, in 1860, is similar in colour and markings to the egg of the Tasmanian species, $S$. arguta. Long diameter $1 \cdot 77$ inch, short diameter $1 \cdot 17$. 


\section{Strepera melanoptera, Gould.}

This bird is found breeding in South Australia. It constructs a large open nest of sticks and twigs, lined inside with fibrous roots and grasses, and usually placed in the topmost branches of a Eucalypt. Two eggs of this species in the Dobroyde collection, taken by Mr. Gardner in 1863, are similar in form to those of $S$. arguta; they are of a light purple or rich vinous-brown ground colour, with large irregularly shaped markings of slaty-brown evenly dispersed over the surface of the shell. Length (A), 1.6 $\times$ 1.18 inch; (B), $1.65 \times 1.19$ inch.

\section{Rhipidura Diemenensis, Sharpe.}

Two eggs taken near Hobart in October, 1885, are of a dull white colour, thickly freckled all over with creamy-brown markings, but more particularly towards the larger end. Length (A), $0.61 \times 0.47$ inch; (B), $0.6 \times 0.47$ inch.

\section{Malurus cyanochlamys, Sharpe.}

Specimens of this bird were obtained on the Herbert River, Queensland, in November, 1868, together with the nest and eggs. The nest is a dome-shaped structure, with an entrance in the side, constructed of dried grass intermingled with spiders' webs, and lined inside with feathers, hair, \&c.; it was placed in a thick bush close to the ground. Eggs four in number for a sitting, fleshywhite sprinkled all over with pale reddish-brown markings; in one specimen (A) forming a coalesced patch on one end. Length (A), $0.68 \times 0.5 \mathrm{inch} ;(\mathrm{B}), 0.68 \times 0.5 \mathrm{inch} ;(\mathrm{C}), 0.66 \times 0.51$ inch; (D), $0.67 \times 0.48$ inch.

\section{Acanthiza inornata, Gould.}

This bird is found in the southern portions of Western and South Australia, being particularly abundant in the neighbourhood of King George's Sound in the former colony, where Mr. Masters succeeded in obtaining a number of specimens during 1868, likewise the nest and eggs. 
A nest of this species now before me, taken from the Australian Museum collection, is a dome-shaped structure composed of the dried wiry stems of a Drosera, and the flowering portions of the Banksia cones, spiders' webs, \&c., all matted up together, and lined inside with the white downy seeds of some composite plant. It measures exteriorly four and a-quarter inches in height, by three inches in width; the aperture which is oval and near the top being one inch high, by one and a-quarter inch in width. The nest is firmly packed in the upright forked branches of a Banksia, and was placed about five feet from the ground; it contained two eggs of a fleshy-white ground colour, freckled all over with irregularly shaped markings of a reddish-brown, particularly towards the larger end where they form a well-defined zone. Length (A), $0.7 \times 0.52$ inch; (B), $0.69 \times 0.52$ inch.

I have described the above nest and eggs upon the authority of Mr. Geo. Masters, who assures me there is not the slightest doubt about them, he having personally taken them on the 3rd of Dec., 1868, at King George's Sound, Western Australia.

Mr. Gould in his 'Handbook to the Birds of Australia,' Vol. I., p. 371, writes of the nest of this species, as being "composed of grasses lined with a few feathers, and the eggs five in number, of a white colour, slightly tinged with greenish grey."

I am inclined to believe that Mr. Gould has described the nest and eggs of some other bird, probably one of the Ploceidce family, as neither the materials of which the nest is composed, nor the number and colour of the eggs, agree with what obtains in the case of the other members of the genus Acanthiza.

\section{Acanthiza uropygialis, Gould.}

For the eggs of this species I am indebted to Mr. K. H. Bennett, who procured them at Mossgiel, on the 15th of October, 1886. The nest, he informs me, was similar to that of A. pyrrhopygia, and was built in a low thickly-foliaged tree about five feet from the ground. Eggs three in number for a sitting, of a delicate fleshy-white, minutely freckled all over with light reddish-brown 
markings, but chiefly towards the larger end, where they form an ill-defined zone. Length (A), $0.65 \times 0.5$ inch; (B), $0.65 \times 0.48$ inch; $(\mathrm{C}), 0.66 \times 0.48$ inch.

\section{Poephila acuticauda, Gould.}

Of this handsome bird, the late Mr. Boyer-Bower procured a fine series, while collecting in North Western Australia. It breeds, like its ally $P$. cincta of the Eastern Coast, in the long grass and low bushes, building a flask-shaped nest of grasses, and laying usually five eggs for a sitting. Eggs white, somewhat lengthened in form, measuring as follows:-Length (A), $0.68 \times 0.48 \mathrm{inch}$; (B), $0.65 \times 0.4$ inch; (C), $0.69 \times 0.46$ inch; (D), $0.71 \times 0.48$ inch; (E), $0.65 \times 0.43$ inch.

September and the three following months constitute the breeding season of this species.

Acanthorhynchus dubius, Gould.

Some ornithologists do not consider this a good species; $\mathrm{Mr}$. Gould, himself, who first pointed out the difference from the Northern and Eastern Australian Continental forms, inclining to believe them identical ; but as the Tasmanian bird is smaller in all its admeasurements, and much richer and deeper in the tints of the under surface, I give the description of a set of eggs taken near Hobart, in October, 1885.

Eggs two in number for a sitting, of a pale buff, approaching a light saturnine red on the larger end, where they are minutely spotted with irregularly shaped markings of deep chestnut-brown, and a few nearly obsolete spots of bluish-grey. Length (A), $0.73 \times 0.53$ inch; (B), $0.75 \times 0.54$ inch.

\section{Zosterops flavogularis, Masters.}

This very distinct and well-marked species was found tolerably abundant at Cape York and the adjacent islands, by the members of the 'Chevert' Expedition in 1875.

A nest of this species now before me, taken by Mr. George Masters at Warrior Island on the 27 th of June, is a deep 
cup-shaped structure composed of the dried skeletons of leaves, held together with spiders' webs, and neatly lined inside with fine wiry grasses, the whole exterior surface being covered with thin broad strips of perfectly white semi-transparent paper-like bark of a Melaleuca, which gives it a very beautiful appearance. Exterior diameter three one-eighth inches, depth two inches ; internal diameter one and three-fourths inch, depth one and a-half inch. The nest was attached by the rim to the thin branches of a shrub, about five feet from the ground. The eggs were two in number, but four is the full complement for a sitting, of a uniform pale bluish-green, both specimens giving exactly the same measurements, viz.: 0.72 inch in length, by 0.5 inch in breadth.

Through the kindness of the Hon. Wm. Macleay, I have been permitted to examine and describe a number of nests and eggs in the Macleayan Museum, from which the above description is taken. I am also indebted to Mr. George Masters, the Curator, for supplying me with all the available information relative to the taking of the same.

\section{Sittella pileata, Gould.}

For the nest and eggs of this species, together with the bird shot therefrom, I am indebted to Mr. James Hill, of Kewell, Victoria, who procured them on the outskirts of the Mallee country in the Wimmera district, in September, 1882. The nest was built in the upright fork of a Casuarina about fifteen feet from the ground, and is similar in every respect to that of $S$. chrysoptera; hence its description would be merely a repetition of that of the nest of the latter species. Eggs three in number for a sitting, the ground colour darker, and the blotches heavier, than in S. chrysoptera, being a deep bluish-white, with long slaty-black markings, while appearing underneath the surface of the shell are large superimposed blotches of dark lilac, which in some instances are confluent; the markings on the under surface are much larger and more numerous than on the outer surface of the shell. Length (A), $0.66 \times 0.51$ inch; (B), $0.66 \times 0.53$ inch ; (C), 0.67 $\times 0.54$ inch. 


\section{Scythrops Nove hollandie, Lath.}

This bird is universally distributed over the whole Continent of Australia, and one or two stragglers have even been found in Tasmania.

Dr. Hurst has kindly permitted me to describe an egg of this species from his collection, which, he införms me, was taken from the oviduct of a bird shot at Kempsey on the Macleay River, during the first week in November, 1884, and which he exhibited at a Meeting of this Society in the same month.

Ground colour dull white, with faint washed-out pinkish spots and minute dots, also some of a light yellowish-brown tinge; appearing as if beneath the surface of the shell at the apex of the thick end are others of a light purplish-brown, becoming confluent, and forming a very indistinct patch, intermingled with some of a brownish shade. All the markings are very ill-defined, and the egg closely resembles a very large and washed-out specimen of the egg of Grallina australis. Length, 1.5 × 1.05 inch.

\section{Megaloprepia assimilis, Gould.}

The Allied Fruit Pigeon is universally dispersed over the Cape York Peninsula, and as far south as the neighbourhood of Rockingham Bay.

A nest of this species found at Cape York by Mr. George Masters, on the 17th of September, 1875, from which the bird was flushed, and procured, was simply a few dried sticks placed cross-wise on a horizontal branch of a tree about eight feet from the ground; it contained two eggs, perfectly white, rather elongated in form and pointed at the smaller ends, in a very advanced state of incubation. An average specimen measures 1.4 inch in length, by 0.95 inch in breadth. (From the Macleyan Mus. Coll.).

\section{Pezoporus formosus, Lath.}

Dr. Ramsay informs me this bird used to breed freely in the neighbourhood of Appin in the long tussocky grass, during the months of September, Octover, and November, and that the young birds afforded excellent sport about the end of January. 
A nest before me is composed of rushes and wiry grass, bitten into suitable lengths, and bent round and interwoven here and there into a platform of about half an inch in thickness; a piece of Lycopodium also being worked into it. The diameter of the nest is 4.5 inches. Eggs white, and three in number for a sitting, shell smooth. Length (A), 1.03 × 0.85 inch; (B), $1.01 \times 0.85$ inch; (C), $1.06 \times 0.85$ inch. (Dobr. Mus. Coll.). 


\section{$2 \mathrm{BHL}$ Biodiversity Heritage Library}

North, Alfred J. 1887. "Notes on the nests and eggs of certain Australian birds." Proceedings of the Linnean Society of New South Wales 2, 405-411. https://doi.org/10.5962/bhl.part.29189.

View This Item Online: https://www.biodiversitylibrary.org/item/21749

DOI: https://doi.org/10.5962/bhl.part.29189

Permalink: https://www.biodiversitylibrary.org/partpdf/29189

\section{Holding Institution}

MBLWHOI Library

\section{Sponsored by}

MBLWHOI Library

\section{Copyright \& Reuse}

Copyright Status: NOT_IN_COPYRIGHT

This document was created from content at the Biodiversity Heritage Library, the world's largest open access digital library for biodiversity literature and archives. Visit BHL at https://www.biodiversitylibrary.org. 